\title{
THE VOLUNTARY ASSOCIATIONS OF GERMAN SOCIAL DEMOCRACY: SEPARATION AND RESISTANCE
}

Jointly sponsored by the AHA and the Association of Voluntary Action Scholars, this session at the Chicago convention featured two prominent historians with a long-standing interest in German Social Democracy, Vernon L. Lidtke (Johns Hopkins University) and William S. Allen (State University of New York, Buffalo.)

Professor Lidtke's report, "Social Democratic Cultural Organizations in Imperial Germany," despite its title dealt with singing societies, particularly in Weinheim an der Weinstrasse. Although the subject matter at first seemed excessively narrow, the speaker used it to draw some broad and interesting inferences. These singing societies represented one case among many of the workers' exclusion from the established mainstream of German social life; they existed because workers were blackballed from existing middle-class groups. Consequently, these workers' societies reflected a sense of exclusion and exclusivity in their membership, in their singing repertoire of working class songs, and in the names of their societies, names such as "Lassale," "Freedom," "Progress," and "Forward." Lidtke's research did, however, reveal certain characteristics of in tegration into the larger society. Such society names as "Germania," or "Teutonia," evidenced a national consciousness. Folk songs, as well as folk costumes at song festivals, testified to a sense of local tradition; and the presence of non-workers in some societies revealed a dilution of the exclusive working class outlook. Sociability mattered a great deal, and it had little to do per se with exclusion or integration of the working class. Members joined to have a good time and quit when they lost enthusiasm. Most societies engaged skilled musicians as choir directors, and the more emphasis societies and directors placed on music, the more considerations of sociability and class receded in to the background. The larger society of Germany reacted in varying ways to the workers' singing societies. On occasion, municipalities welcomed, even subsidized, songfests and parades (Nuremberg did so) while some cities (Breslau, e.g.) absolutely forbade public festivities.

The conclusion, stated tentatively because the investigation did not warrant so sweeping a judgment. was that analysts dealing with organizations such as the SPD need a new analytical model to replace the simpler one used by such prominent investigators as Roth who analyzed the SPD in terms of its exclusion from the larger society. The case of the singing societies clearly reveals instances of exclusivity and class consciousness alongside instances of values shared with the larger society and certain characteristics such as musicianship and sociability which were neutral in terms of class relations. Mr. Lidtke proposed an alternative analytical model which would deal with the multiple points of contact between the SPD and the larger society, a model which can deal with the complex of integrations and exclusions.

A model such as the one proposed by Mr. Lidtke would seem almost self-evident to an observer familiar with only the basic outlines of the SPD's development. The Party's consistent support of and accommodation to the existing political-economic order since at least 1914 reveal a strong basic identification with that order despite many very real instances of exclusion and exclusiveness. Since their attitudes and activities in politics and on the large scale reveal complex patterns of rejection and interaction, it stands to reason that the Socialists' cultural organizations in the Imperial period should 
have combined these various characteristics. Mr. Lidtke's evidence and reasoning on this point are welcome.

While Mr. Lidtke's paper delivered rather more than it had promised at the outset, the opposite holds for "Social Democratic Organizations and the Anti-Nazi Underground" by William S. Allen. The comparison detracts in no way from Mr. Allen's manifest talent as historian and stylist, but rather it reflects the Socialists' own failures. The Socialists ruled out from the start the only conceivably effective means of resistance, i.e., assassinating Hitler, because their Marxian outlook held such individual terror a waste of effort. They considered armed resistance only to reject it out of hand. For about two years, they maintained an astonishingly well-circulated clandestine press, but to what purpose? When the Gestapo finally broke this up, the Socialists decided, logically enough, that the effort was simply not worth the risk. They sharply curtailed it, and until the end of the war, they were able simply to maintain some sort of organization in being, reconstituting their party immediately upon the war's end.

In the final analysis, then, here was a case where some sort of resistance, at least an inward resistance, grew out of an existing organization rather than the other way around. The activities engaged in were possible because of the close ties of trust and comradeship built up over the years before 1933. The only achievement was to keep the Party intact.

Both commentators, Professors Charles K. Warriner and Morris Janowitz, are sociologists. In particular, Mr. Warriner found Mr. Lidtke's work in close agreement with his own findings on voluntary associations (square dance groups in Missouri). Such evaluations are useful since historians have been criticized of late for dabbling in social science without understanding the subject area and techniques.

\author{
Donald B. Pryce \\ The University of South Dakota
}

\title{
SECOND CONFERENCE OF THE WESTERN SOCIETY FOR FRENCH HISTORY
}

There were several papers among those presented at this meeting (November 21-23, 1974, in San Francisco) which are of special interest to members of the study group. I will briefly discuss those papers I heard in person and will also list other papers that I was unable to attend.

In a session on Women in France from the 17th to the 19th Century, Marilyn Boxer (Women's Studies, San Diego State University) presented a paper entitled "Foyer or Factory: Working Class Women in 19th Century France." Ms. Boxer's paper dealt with the contlict between Marxian socialistfeminist ideology and the realities of working-class tradition and life patterns as expressed in French socialist congresses between 1866 and the first World War. She underscored the strength of the Proudhonian tradition among French workers concerning woman's place in the home, giving pithy examples of the hostility exhibited by articulate workingmen to the very notion of women in the 